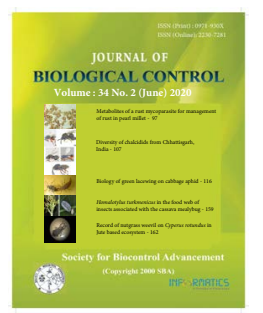

Research Article

\title{
Behavioural response of specific larval endoparasitoid, Apanteles machaeralis (Wilkinson) to volatile cues from its host insect, Diaphania indica (Saunders) and the host plant (Cucumis sativus L.)
}

\author{
U. VENUGOPAL ${ }^{1 *}$, P. D. KAMALA JAYANTHI ${ }^{2}$, P. SARAVAN KUMAR ${ }^{2}$, K. S. JAGADEESH ${ }^{1}$ and K. MURALI \\ MOHAN ${ }^{1}$ \\ ${ }^{1}$ Department of Entomology, University of Agricultural Sciences, Bangalore - 560065, Karnataka, India \\ ${ }^{2}$ Division of Entomology and Nematology, ICAR-Indian Institute of Horticultural Research, Hessaraghatta Lake PO, Bangalore - 560089, \\ Karnataka, India \\ *Corresponding authorE-mail: uvenu22@gmail.com
}

\begin{abstract}
Apanteles machaeralis (Wilkinson), a braconid specialist larval endoparasitoid of Diaphania indica occurs naturally causing significant levels of parasitism. The present study explores the response of the A. machaeralis to odour cues from $D$. indica damaged cucumber plant as well as host larvae. Different odour treatments namely, $D$. indica larval body volatiles $\left(\mathrm{T}_{1}\right)$, volatiles from larval excreta $\left(\mathrm{T}_{2}\right)$, volatiles from larvae + excreta $\left(\mathrm{T}_{3}\right)$, volatiles from $D$. indica body wash $\left(\mathrm{T}_{4}\right)$, volatiles from the healthy, mechanically damaged and $D$. indica infested cucumber plants (HIPVs) were collected using headspace analysis and the response of female $A$. machaeralis was studied using olfactometer assays. Results of the study conclusively indicated that A. machaeralis is highly attracted to host larval body wash as parasitic wasps spent significantly more time made more entries into the treated region in single as well as dual choice assays. The electoantennographic response (EAG) further supported the olfactometer bioassays. The GC-MS analysis revealed significant differences in the volatile emissions of different treatments studied. The utilization of host insect body cues and HIPVs in the host recognition by the specialist endoparasitoid $A$. machaeralis is discussed in detail.
\end{abstract}

KEY WORDS: Cucumber moth, HIPVs, olfactometer assays, specialist parasitoid, volatiles

(Article chronicle: Received: 10-03-2020; Revised: 18-05-2020; Accepted: 25-05-2020)

\section{INTRODUCTION}

Plants produce a significant number of volatile plumes (Herbivore Induced Plant Volatiles, HIPVs), when damaged by herbivores. These organic compounds have heterogeneous behavioural functions across multi-trophic levels (Turlings et al., 1990; De Moraes et al., 1998; Pare and Tumlinson, 1999; Mumm and Hilker, 2005; Kamala Jayanthi et al., 2020). These HIPVs are specific to each plant species as well as herbivores and are perceived by neighbouring plants (Steidle and Schöller, 1997; Sullivan and Berisford, 2004), conspecific/ heterospecific herbivores associated with the crop (Mumm and Hilker, 2005; Wei and Kang, 2006; Ngumbi and Fadamiro, 2012) and their natural enemies (Wei et al., 2007). HIPVs often guide natural enemies and help them locate their prey thereby serving as long range radar (Rutledge, 1996). Location of host habitat and host insect is crucial for natural enemies as it impacts their offspring's fitness and survival (Schnee et al., 2006; van Dam et al., 2010). In the complex odour network the natural enemies must fine tune their olfactory system to its finest to discriminate and track down the host's habitat location (= long range signals) and the host's micro-habitat location (= short range signals). Once they locate the host's habitat, they may depend on volatile cues (= kairomones) produced by the host insect itself. Thus, at short distances, volatile cues produced by the host insect serve as an arrestant for natural enemies (Meiners et al., 2002; Rains et al., 2004; Harris et al., 2012). Specialist parasitoids whose degree of host specificity is much narrower compared to generalists must depend on specialized volatile cues from suitable host larvae and their host plant to locate them and thus they have been considered as good models for insect olfaction studies (Meinersv et al., 2002; Rains et al., 2004; Harris et al., 2012).

Braconid, Apanteles machaeralis (Wilkinson) is a major specialist larval endoparasitoid of Cucumber moth, Diaphinia indica (Saunders), which is a serious pest of several cucurbitaceous crops. The female A. machaeralis oviposits inside the $D$. indica larva and the emerging parasitoid larvae 
feed on the host's larval body tissues causing its death. The host location ability of $A$. machaeralis seems to be highly specialized as the female parasitoidis able to detect the presence of a host larva, even when surrounded by a very complex odor background (Kigathi et al., 2009; de Rijk et al., 2016). Whether A. macheralis depends on the olfactory cues emanating from the $D$. indica infested host plant or host insect $(=D$. indica larvae) in the host location processes has not been investigated till date. The present study was aimed to identify the source of olfactory cues that the female parasitoid, A. macheralis uses for locating its $D$. indica larval host in infested cucumber plant, Cucumis sativus L. Volatiles from $D$. indica infested cucumber plant, healthy cucumber plant, mechanically damaged cucumber host plant, $D$. indica larvae, $D$. indica larval faeces served as odour sources to evaluate the behavioural response of $A$. macheralis females.

\section{MATERIALS AND METHODS}

\section{Host insect}

Larvae of cucumber moth, D. indica were collected from the experimental fields of ICAR-Indian Institute of Horticultural Research (IIHR), Bangalore, Karnataka, India.

\section{Parasitoid}

Diaphinia indica larvae which were parasitized by Apanteles machaeralis were collected from the IIHR experimental fields and brought to the laboratory. The parasitized larvae along with the parasitoid cocoons were kept in a plastic container $(45 \times 50 \mathrm{~cm})$ and were maintained at ambient conditions (12L:12D, $27 \pm 1^{\circ} \mathrm{C}, 75 \%$ relative humidity) until the emergence of the adult wasps. The emerged adult wasps ( $\hat{\sigma}$ and 9 ) were provided with $10 \%$ honey on cotton swab ad libitum and allowed to mate. Later, the mated females were separated and were used for behavioural assays.

\section{Host plant}

The selected host plant, C. sativus was maintained in grow polybags $(6 \times 8$ ") without any pesticide application. To avoid insect pest infestation, regular water sprays were given at frequent intervals.

\section{Host plants infested with Diaphinia indica larvae}

For the establishment of infested cucumber plants, mixed instars of $D$. indica larvae $(\mathrm{n}=40)$ were released on healthy $C$. sativus plants with the help of a camel hair brush and were covered with a white transparent polythene cover to avoid larval escape. Holes were made on the cover using a needle to allow aeration. The larvae were allowed to feed on the plants continuously for $24 \mathrm{~h}$, and later the larvae were removed from the plants. The plants which were fed by $D$. indica larvae were used for the collection of plant volatiles
(=HIPVs) through air entrainment.

\section{Host plants with mechanical damage}

To simulate mechanical damage, the leaves of healthy $C$. sativus plants were damaged using scissors. Such damaged plants were used to collect plant volatiles through air entrainment.

\section{Host plant volatiles}

Plant volatiles from healthy, $D$. indica infested as well as mechanically damaged $C$. sativus plants were collected through air entrainment as per the procedure described by Jayanthi et al., (2012). The test plants were draped with autoclaved polythene bags $(41 \times 32.5 \mathrm{~cm})$ with both outlet and inlet ports inside the cover. The cover was tightly tied at the base of the plant using rubber bungs and silica wool to prevent air passage. Volatiles were collected onto Porapak Q (50 mg, 60/80 mesh; Supelco, Sigma Aldrich, St Louis, USA) which was placed in a glass tube $(5 \mathrm{~mm}$ dia.) and inserted into the outlet collection port, placed in the cover. Further, pumps drew air $(800 \mathrm{~mL} / \mathrm{min})$ through these tubes. Air that was purified by passage through an activated charcoal filter was pumped into the cover through the inlet port $(400 \mathrm{~mL} /$ $\mathrm{min})$. All connections were made with PTFE tubing with brass ferrules and fittings (Swagelok, India) and sealed with PTFE tape. Porapak Q tubes were heated at $100^{\circ} \mathrm{C}$ for $2 \mathrm{~h}$ under a stream of purified nitrogen to remove contaminants. Volatiles were collected from different treatments for 24 $\mathrm{h}$ and the Porapak Q columns were eluted with $750 \mu$ l of redistilled diethyl ether with an internal standard $(5 \mu \mathrm{g} / \mu \mathrm{L}$ of ethylbenzoate, $99.9 \%$ pure, Sigma Aldrich, U.S.A.; Anfora $e t$ al., 2009). The collected volatile samples were stored in a freezer $\left(-20^{\circ} \mathrm{C}\right)$ until further use.

\section{Host larval odours}

A total of four different types of host insect odours $(D$. indica larval body odours $\left(\mathrm{T}_{1}\right), D$. indica excreta odours $\left(\mathrm{T}_{2}\right)$, $D$. indica larvae + excreta odours $\left(\mathrm{T}_{3}\right), D$. indica larval body wash $\left(\mathrm{T}_{4}\right)$ were collected for the study. Of which, the first three host insect odours namely $\mathrm{T}_{1}, \mathrm{~T}_{2}, \mathrm{~T}_{3}$ were collected through air entrainment from different treatments namely $D$. indica larvae $(\mathrm{n}=125), D$. indica larval excreta $(4.60 \mathrm{~g})$ and $D$. indica larvae + excreta $(\mathrm{n}=125,4.60 \mathrm{~g}$ respectively) as per the procedure described by Jayanthi et al., (2012). All the three treatments were placed individually inside a cylindrical glass vessel and closed with a lid having collection and inlet ports at the top. The flange on the open end of the glass vessel was clipped to make the vessel air tight. Volatiles were collected on Porapak Q as explained above. Before the volatile collection, glassware was washed with liquid detergent, rinsed with distilled water and acetone and was then dried in an oven at $180^{\circ} \mathrm{C}$ for $2 \mathrm{~h}$. The Porapak Q 
columns used for the collection of volatiles were eluted with redistilled diethyl ether and the volatile samples were stored in a freezer $\left(-20^{\circ} \mathrm{C}\right)$ until further use.

To obtain $D$. indica larval body wash $\left(\mathrm{T}_{4}\right)$, a total of 125 larvae of $D$. indica were placed in $50 \mathrm{~mL}$ beaker and $5 \mathrm{~mL}$ of $n$ - hexane $(99.9 \%)$ was added and left for 5-10 min. The $n$-hexane filtrate was collected and into which $2 \mathrm{~g}$ of sodium sulphate was added to remove the moisture traces. The final filtrate was reduced to $500 \mu \mathrm{l}$ using a slow stream of nitrogen and an internal standard of $5 \mu \mathrm{g} / \mu \mathrm{L}$ of ethyl benzoate was added to the extract for chemical quantification. This filtrate which served as $D$. indica larval body wash $\left(\mathrm{T}_{4}\right)$ was stored in a freezer $\left(-20^{\circ} \mathrm{C}\right)$ until further use.

\section{Electroantennographic bioassay (EAG)}

Electroantennogram (EAG) recordings were made as described by Cork et al., (1990) using 2-4 days old mated $A$. machaeralis females. In this bioassay, empty air and honey were used as negative and positive controls respectively. The olfactory stimuli were obtained by impregnating $10 \mu \mathrm{l}$ of odour samples from host plant and host larvae of $D$. indica $\left(\mathrm{T}_{1}-\mathrm{T}_{7}\right)$ onto separate filter paper strips (Whatman No.1, $6 \mathrm{~cm}$ length $\mathrm{x}$ $0.5 \mathrm{~cm}$ breadth). The solvent was then allowed to evaporate for $1 \mathrm{~min}$ before placing the filter papers inside the glass pasture pipettes $(10 \mathrm{~cm}$ length and $6 \mathrm{~mm}$ outer diam.). Stimulation of antennal preparation was carried out by means of controlled airflow $(300 \mathrm{~mL} / \mathrm{min})$ through the pipette with the filter paper. By injecting a puff of purified air $(0.5 \mathrm{sec})$, odour stimulation was administered, amplified and recorded using Autospike software (Syntech EAG Model IDAC-4, Intelligent Data Acquisition Controller). To measure stimulus-response, the test stimuli were successively given along with interspersed control stimulation. Between stimulus presentations, purified air was blown over the antennal preparation for at least 30 sec. The EAG Probe was set at a sampling rate of 100 with a filter rate of 0-32 Hz. The responses (amplitudes) to the host plant volatiles are expressed as mean of all recorded antennal depolarizations.

Antenna was changed for each replication and a total of seven replicates were carried out for each stimulus. Antennal response for the test volatiles of different treatments were recorded based on the downward deflection signal (in $\mathrm{mV}$ ) of gravid female antenna for all host plants and host larvae volatiles and the data were subjected to one-way ANOVA using Graph pad prism (version 7.03)

\section{Gas chromatography coupled mass spectrometry analysis (GC-MS)}

Chemical composition of Porapak Q elutes of different treatments viz., larval body volatiles of $D$. indica $\left(\mathrm{T}_{1}\right)$, volatiles from larval excreta $\left(\mathrm{T}_{2}\right)$, volatiles from larvae + excreta $\left(\mathrm{T}_{3}\right)$, larval body wash $\left(\mathrm{T}_{4}\right)$, volatiles of $D$. indica infested cucumber plant $\left(\mathrm{T}_{5}\right)$, volatiles from healthy cucumber $\left(\mathrm{T}_{6}\right)$, volatiles from mechanical damaged cucumber plant $\left(\mathrm{T}_{7}\right)$ were analysed by using GC-MS Agilent 7890B GC system equipped with Mass Spectrophotometry (Agilent 5977 MSD).A capillary column Agilent J \& W (HP-5 MS UI) of $30 \mathrm{~m}$ length, $0.250 \mathrm{~mm}$ Diameter and $0.25 \mu \mathrm{m}$ film thickness was used to examine the samples. The thermal programme was initially set at $60^{\circ} \mathrm{C}$ for 1 min later ramped at $15^{\circ} \mathrm{C} / \mathrm{min}$ up to $240^{\circ} \mathrm{C}$ and held for $2 \mathrm{~min}$ the flow rate of $1 \mathrm{~mL} / \mathrm{min}$ with helium as the carrier gas. MS full scan mode $(70 \mathrm{eV})$ and AMU ranged from 40 to 450 . One micro litre of the sample was injected in split less mode ratio $(40 \mathrm{~mL} / \mathrm{min})$ with injection temperature of $270^{\circ} \mathrm{C}$. Total volatile emissions were calculated by the sum of all GC-FID peak areas in the chromatogram and individual compounds were quantified as relative per cent area. The compounds were identified by $\mathrm{GC}$ retention time, mass spectrum and KOVATS index (C7 to $\mathrm{C} 30$ homologous series of $n$-alkenes as standard, SigmaAldrich; Kovats, 1965) using NIST 14 software. Identified compounds were authenticated by co-injecting standard synthetic compounds along with the samples (Jayanthi et al., 2012).

\section{Olfactometer bioassays}

To study the behavioural responses of female $A$. machaeralis to different test volatiles $\left(\mathrm{T}_{1}-\mathrm{T}_{7}\right)$, olfactometer bioassays were carried out using a circular Perspex four-arm olfactometer $[120 \mathrm{~mm}$ dia.], placed inside a cage $(0.62 \mathrm{~m}$ length $\times 0.62 \mathrm{~m}$ wide $\times 0.62 \mathrm{~m}$ height), illuminated from above by diffused, uniform lighting using a fluorescent bulb $(15 \mathrm{~W})$ and surrounded by black light proof walls to prevent influence of any external visual stimuli as per the procedure described by Jayanthi et al., (2012). The experiments were conducted at ambient room temperature $\left(27 \pm 1^{\circ} \mathrm{C}\right)$. Prior to the experiment, all glassware was washed with liquid detergent, rinsed with acetone and distilled water and baked in an oven overnight at $180^{\circ} \mathrm{C}$. Perspex components were washed with Teepol solution, rinsed with $80 \%$ ethanol and distilled water, and were left to air-dry. The bottom of the apparatus was lined with filter paper (Whatman No $1,12 \mathrm{~cm}$ dia.) and air was drawn through the four arms towards the centre at $350 \mathrm{~mL} \mathrm{~min}^{-1}$.

Individual adult female parasitoids were introduced into the central chamber through a hole on the top of the olfactometer. Each parasitoid was given 2 min to acclimatize in the olfactometer, after which the experiment was run for $15 \mathrm{~min}$ for each replicate.

Two series of bioassays namely single choice and dual 
choice assays were carried out to study the behavioural response of female $A$. machaeralis to different odour samples. In single choice assay, all odour samples $\left(\mathrm{T}_{1}-\mathrm{T}_{7}\right)$ were tested against solvent control (diethyl ether/hexane as the case may be). Each replicate involved one treated arm and the remaining three arms served as controls. In dual choice assay, the odour samples that elicited significant response in female $A$. machaeralis parasitoid were compared in different combinations $\left(\mathrm{T}_{1}\right.$ vs $\mathrm{T}_{4} ; \mathrm{T}_{1}$ vs $\mathrm{T}_{5} ; \mathrm{T}_{4}$ vs $\left.\mathrm{T}_{5}\right)$. Here, each replicate involved two treated arms and the remaining two served as control arms (solvent). The test samples $(10 \mu \mathrm{l})$ were applied to a filter paper and the solvent was allowed to evaporate prior to placement. Filter paper strips with solvent $(10 \mu \mathrm{l})$ served as control. Ten $(\mathrm{n}=10)$ replicates were carried out for each assay.

Observations on the time spent and the number of entries made into each arm were recorded using Olfa software (F. Nazzi, Udine, Italy). Single choice and dual choice assays data were subjected to $t$ - test and one way ANOVA respectively using Graph pad prism (v7.03).

\section{RESULTS AND DISCUSSION}

Single choice assays with different odour treatments along with the solvent control against Apanteles machaeralis females revealed that the specialist parasitoids were significantly attracted to $\mathrm{T}_{1}$ (Diaphania indica larval body volatiles), $\mathrm{T}_{4}$ (larval body wash) and $\mathrm{T}_{5}$ (HIPVs from $D$. indica infested Cucumber plant) as they spent significantly more time $(\mathrm{min})$ in the treated regions over control. In case of $\mathrm{T}_{1}$, A. machearlis females spent significantly more amount of time in the treated region over control [Time spent $(\mathrm{min})$ : Mean \pm S.E, $2.75 \pm 0.37$, control $=1.89 \pm 0.18, P=0.02]$. However, no significant difference was noticed among the number of entries made into the treated as well as control regions [Entries (number): Mean \pm S.E, $3.80 \pm 0.84$, control $=4.53 \pm 0.27, P=\mathrm{NS}$ ). In case of $\mathrm{T}_{4}$, the female parasitoids spent significantly more time and made more entries in the treated region compared to the control $\left[\mathrm{T}_{4}\right.$ time spent $(\mathrm{min})$ : Mean \pm S.E, $3.36 \pm 0.40$, control $=2.86 \pm 0.13, P=0.001$; Entries (number): Mean \pm S.E; $16.60 \pm 1.48$, control $=11.77$ $\pm 1.58, P=0.003]$. Similar to $\mathrm{T}_{1}$, in case of $\mathrm{T}_{5}$ female parasitoids spent significantly more amount of time in the treated region over control but no significant difference was found with respect to the number of entries made $\left[\mathrm{T}_{5}\right.$ : time spent (min): Mean \pm S.E, $3.17 \pm 0.58$, control $=2.46 \pm 0.32$, $P=0.004$; entries (number): Mean \pm S.E, $2.90 \pm 0.46$, control $=2.23 \pm 0.20, P=0.76]$.

The parasitoids did not respond to the volatiles of the remaining treatments viz., $\mathrm{T}_{2}$ (larval excreta), $\mathrm{T}_{3}$ (larvae + excreta) $\mathrm{T}_{6}$ (healthy cucumber plant) and $\mathrm{T}_{7}$ (mechanically damaged cucumber plant) $\left[\mathrm{T}_{2:}\right.$ time spent (min): Mean \pm S.E, $2.63 \pm 0.56$, control $=1.99 \pm 0.27, P=0.360$; entries (number): Mean \pm S.E, $6.40 \pm 1.37$, control $=5.56 \pm 1.20$, $P=0.10 ; \mathrm{T}_{3}$ : time spent $(\mathrm{min}):$ Mean \pm S.E, $2.17 \pm 0.41$, control $=2.19 \pm 0.19, P=0.95$; entries (number): Mean \pm S.E, $6.60 \pm 1.63$, control $=7.03 \pm 1.31, P=0.75 ; \mathrm{T}_{6}$ : time spent (min): Mean \pm S.E, $1.57 \pm 0.38$, control $=2.23 \pm 0.20$, $P=0.17$; entries (number)Mean \pm S.E: $6.70 \pm 1.14$, control $=7.53 \pm 0.67, P=0.59 ; \mathrm{T}_{7}$ time spent(min): Mean \pm S.E, $1.69 \pm 0.47$, control $=2.54 \pm 0.34, P=0.27$ : entries (number): Mean \pm S.E, $7.60 \pm 1.49$, control $=8.47 \pm 0.99, P=0.33]$.

The step-wise dual choice assays between $T_{1}$ vs $T_{4}$, $\mathrm{T}_{4} \mathrm{vs}_{5}$, and $\mathrm{T}_{1} \mathrm{vs}_{5}$ revealed that in the first combination, the female parasitoids significantly attracted to $T_{4}$ over $T_{1}$ by spending more time and by making more entries into the treated region [time spent $(\mathrm{min})$ : Mean \pm S.E, $\mathrm{T}_{4}=3.26 \pm 0.34$, $\mathrm{T}_{1}=2.27 \pm 0.32$, control $1=1.83 \pm 0.31$, control $2=1.80+$ $0.34, P=0.004$; no of entries (number): Mean \pm S.E, $\mathrm{T}_{4}=13.0$ $\pm 1.90, \mathrm{~T}_{1}=9.10 \pm 1.70$, control $1=8.25 \pm 0.84$, control $2=$ $7.96+0.28, P=0.003]$. In the second combination $\left(\mathrm{T}_{4} \mathrm{vs}_{5}\right)$, the female parasitoids spent significantly more amount of time into the $T_{4}$ region compared to $T_{5}$, however, no significant difference was found for the number of entries made by female parasitoids[time spent ( $\mathrm{min}$ ): Mean \pm S.E, $\mathrm{T}_{4}=3.30$ $\pm 0.26, \mathrm{~T}_{5}=2.01 \pm 0.35$, control $1=2.28 \pm 0.34$, control $2=$ $2.13+0.22, P=0.003$; no of entries: $\mathrm{T}_{4}=6.60 \pm 1.19, \mathrm{~T}_{5}=7.50$ \pm 1.28 , control $1=5.67 \pm 0.94$, control $2=5.01+0.86, P=$ $0.55]$. In the third combination $\left(\mathrm{T}_{1} \mathrm{vs} \mathrm{T}_{5}\right)$, parasitoids did not differentiate the treatments either for time spent or number of entries [time spent $(\mathrm{min})$ : Mean $\pm \mathrm{S} . \mathrm{E}, \mathrm{T}_{1}=1.57 \pm 0.38, \mathrm{~T}_{5}=$ $2.23 \pm 0.20$, control $1=2.04 \pm 0.36$, control $2=2.13+0.26, P$ $=0.75$; entries: $\mathrm{T}_{1}=9.80 \pm 1.67, \mathrm{~T}_{5}=6.50 \pm 1.49$, control $1=$ $5.30 \pm 0.81$, control $2=4.57+0.91, P=0.40]$. The results of the study conclusively indicate that the specific endoparasitoid $A$. machaeralis is highly attracted to host larval body wash $\left(\mathrm{T}_{4}\right)$ in terms of both amount of time spent and no of entries made into the treated region in single choice as well as dual choice assays. However, in case of dual choice assays, though the parasitoids spent significantly more time in $\mathrm{T}_{4}$ over other treatments, they could not differentiate between the treatments $T_{4}$ and $T_{5}$ for number of entries (Fig. 1).

Electroantennographic response of $A$. macheralis to different volatile treatments $\left(\mathrm{T}_{1}-\mathrm{T}_{7}\right)$ revealed that parasitoid female antenna showed significantly high response to larval body wash $\left(\mathrm{T}_{4}: 1.176 \pm 0.257 \mathrm{mV}\right.$; mean amplitude \pm S.E, $P$ $=0.001)$ followed by larval body volatile $\left(\mathrm{T}_{1}: 0.825 \pm 0.128\right.$ $\mathrm{mV}$; mean amplitude \pm S.E, $P=0.002$ ), and infested cucumber plant $\left(\mathrm{T}_{5}: 0.737 \pm 0.204 \mathrm{mV}\right.$; mean amplitude \pm S.E, $P$ $=0.04$ ). The remaining treatments did not elicit significant antennal response in $A$. macheralis [mean amplitude \pm S.E, 

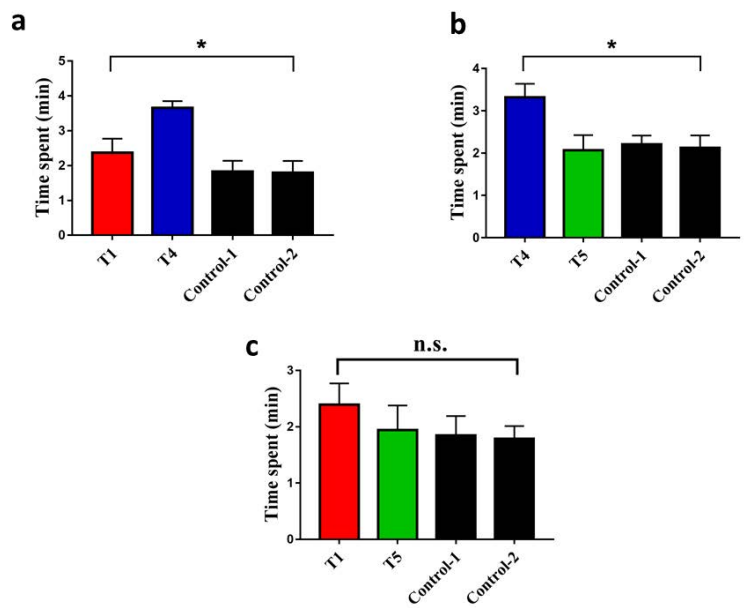

Fig. 1. Dual choice assays showing the response of Apanteles machearalis parasitoid females to (a) $\mathrm{T}_{1} \mathrm{Vs} \mathrm{T}_{4}$ [Larval body volatiles Vs Larval body wash] (b) $T_{4} V s T_{5}$ [Larval body wash Vs Infested cucumber volatiles] (c) $T_{1}$ Vs $T_{5}$ [Larval body volatiles Vs Infested cucumber volatiles]; *P $=0.004$ (a); $\mathbf{P}=\mathbf{0 . 0 0 3}$ (b); n.s. indicates non-significance

$\mathrm{T}_{2}$ : excreta, $0.387 \pm 0.1427 \mathrm{mV} ; \mathrm{T}_{3}$ : larvae with excreta, $0.5878 \pm 0.1514 \mathrm{mV} ; \mathrm{T}_{6}$ : healthy cucumber plant, $0.5478 \pm$ $0.1099 \mathrm{mV} ; \mathrm{T}_{7}$ : mechanically injured cucumber plant, 0.7044 $\pm 0.1255 \mathrm{mV}]$. These results indicated that $A$. machearalis female highly preferred larval body cues and infested host plant volatiles (Fig. 2).

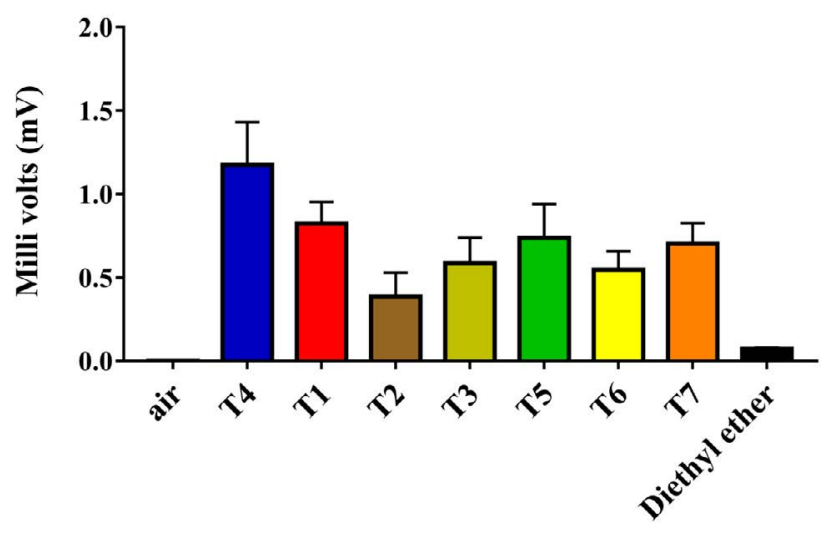

Fig. 2. Electroantennogrphic response of Apanteles machearalis females to $T_{1}$ (Larval body volatiles), $T_{2}$ (Larval excreta), $T_{3}$ (Larva+excreta), $T_{4}$ (Larval body wash), $T_{5}$ (Infested cucumber plant volatiles), $T_{6}$ (Healthy cucumber plant volatiles), $T_{7}$ (Mechanically damaged cucumber plant volatiles)
A comparison of volatile compounds of larval body wash $\left(\mathrm{T}_{4}\right)$, larval body volatile $\left(\mathrm{T}_{1}\right)$ and infested cucumber plant $\left(\mathrm{T}_{5}\right)$ through GC-MS analysis revealed significant differences among the functional groups namely terpenoids, esters \& acids, aromatic hydrocarbons, phenyl propanoids, alkanes, alkenes, methyl pyridines, indole, alcohols, aldehydes and phenols across the treatments (Supplementary Table 1).

The comparison of GC-MS analysis of larval body wash and larval body volatiles revealed significant qualitative and quantitative differences in the volatile compound emissions (Fig. 3). Significant amounts $(>5 \mu \mathrm{g} / \mathrm{mL}$ ) of chemical compounds like 3-carene (6.15), (z)-ocimene (15.91), 9-methylnonadecane (5.04), dodecanal (5.73), $n$-hexadecanoic acid (5.26), $n$-tetradecanoic acid (6.22), trans-isoeugenol acetate (38.40), isobutyl valerate (8.69), H-Indole, 2-(1,1-dimethyl ethyl)- (6.08), -thujaplicin (8.16), trans-phytol (5.76), $n$-eicosane (19.67), 2,5-di-tertbutylphenol (42.67) were exclusively noticed in larval body wash suggesting that these volatile compounds from $D$. indica larval body, individually or in combination would have served as attractive cues to $A$. machaeralis.

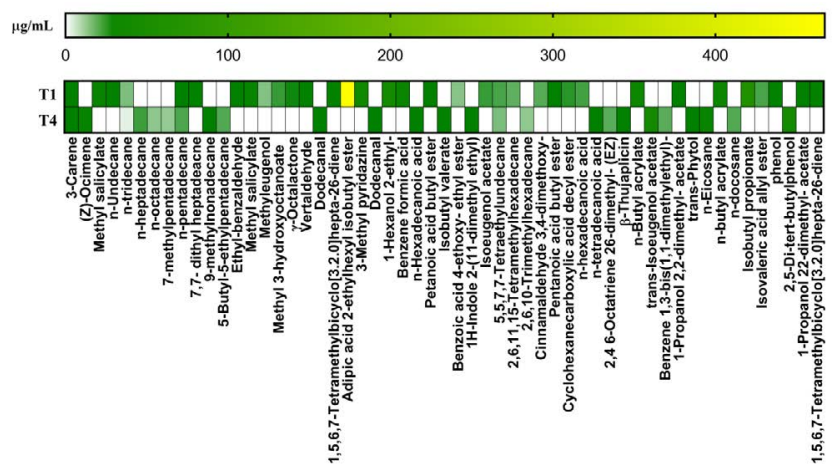

Fig. 3. Heat map showing differences in the volatile compounds of $T 1$ (Larval body volatiles) and $T_{4}$ (Larval body wash)

The volatile emissions of damaged cucumber plant differed qualitatively and quantitatively from healthy as well as mechanically damaged cucumber plant volatiles (Fig. 4). In case of HIPV's released from $D$. indica infested cucumber plant, exclusive presence of significant amounts $(\mu \mathrm{g} / \mathrm{mL})$ of $n$-decane (7.02), $n$-hexadecane (6.99),2,4-dimethylundecane (8.00), 4-methyl octane (6.00), 5,8-diethyl dodecane (10.40), 3-methyl pentadecane (76.11), 4 methyl dodecane (172.58 and4-(1-hydroperoxy-2,2-dimethyl-6-methylenecyclohexyl)-pent-3-en-2-one (8.70) was noticed. Compounds like naphthalene $(44.80 \mu \mathrm{g} / \mathrm{mL}), n$-octadecane $(17.62 \mu \mathrm{g} /$ $\mathrm{mL})$ and 2,6,10-trimethyl pentadecane $(57.73 \mu \mathrm{g} / \mathrm{mL})$ were emitted exclusively my mechanically damaged cucumber plants (Fig. 4). Compounds like $n$-undecane and 4,5 dimethyl nonane exhibited concentration dependent changes across 
the different plant treatments namely healthy (375.63, $249.79 \mu \mathrm{g} / \mathrm{mL}), D$. indica infested $(513.49,419.15 \mu \mathrm{g} / \mathrm{mL})$ and mechanically damaged plants $(1104.49,1602.36 \mu \mathrm{g} / \mathrm{mL})$ respectively. Presence of sesquiterpene compound, farnesene $(8.94 \mu \mathrm{g} / \mathrm{mL})$ was noticed only in healthy cucumber plants (Fig. 4).

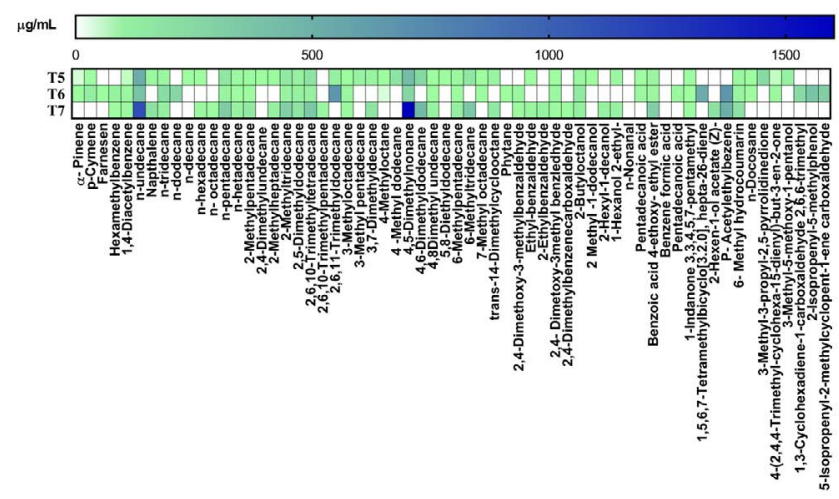

Fig. 4. Heat map showing differences in the volatile compounds of $T_{5}$ (Infested cucumber plant volatiles), $T_{6}$ (Healthy cucumber plant volatiles) and $T_{7}$ (Mechanically damaged cucumber plant volatiles)

The strategy of host location by parasitoids is a systematic process involving series of steps like initial finding of the location of associated plants of the host insects from distance and landing on them, followed by the tracking of specific host insect (herbivore) odours for precise location of its host insect in the final phase of the host location strategy (Rutledge, 1996). In the host-location process of parasitoids, HIPVs play crucial role acting as kairomones /synomones (de Rijk et al., 2016).

In the presents study, the results of single choice fourarm olfactometer assays revealed that female A. machaeralis was highly attracted to volatiles from $D$. indica larval body wash, followed by $D$. indica larval body volatiles and $D$. indica infested cucumber plant. Thus, only host insect associated volatile cues (=larval body odours, $\mathrm{T}_{1}$ and $\mathrm{T}_{4}$ ) and HIPVs from the host plant were found to be attractive to female A. machaeralis (Fig. 4). Previously, Dweck et al., (2010) opined that only host associated volatiles may be attractive or ecologically relevant to parasitoids for the final host location and recognition. Similarly, when choice was given, the females of another specialist parasitoid, Apanteles taragamae were attracted to HIPVs from cucumber plant infested with $D$. indica over healthy and mechanically damaged cucumber plants, Nurkoumar et al., (2017).

In the present study, the volatile cues from larval excreta, larva + excreta, healthy host plant and mechanically damaged host plant did not attract the female $A$. machaeralis indicating
A. machaeralis locates its host insect mainly through HIPVs as well as host insect ( $D$. indica) larval body cues. The EAG response of A.machaeralis to all the volatile treatments $\left(\mathrm{T}_{1}\right.$ $\mathrm{T}_{7}$ ) further supported this where A.machaeralis females showed the highest response to larval body wash followed by larval body volatiles and infested cucumber plant volatiles. The results of dual choice assays added further clarity to the parasitoid's preference. Given a choice, the female A.machaeralis prefers the odour cues from larval body followed by HIPVs from the cucumber plant. Thus, specific larval endoparasitoid, A.machaeralis might use HIPVs from the $D$. indica infested cucumber plant as long-range cues and $D$. indica larval host body cues as short-range cues.

The volatile chemicals from the two treatments of $D$. indica larval body $\left(\mathrm{T}_{1}\right.$ and $\left.\mathrm{T}_{4}\right)$ also differed significantly (Fig. 4). Though in single choice assays both the treatments were found attractive to female parasitoids, later in dual choice assay body wash from $D$. indica larvae (T4) was found to be significantly more attractive. The larval body wash revealed to contain trans-isoeugenol acetate $(38.40 \mu \mathrm{g} / \mathrm{mL}), n$-eicosane $(19.67 \mu \mathrm{g} / \mathrm{mL})$ and 2,5 -di-tert-butylphenol $(42.67 \mu \mathrm{g} / \mathrm{mL})$ in significant amounts, suggesting these volatile compounds from $D$. indica larval body, individually or in combination would have served as attractive cues to female $A$. machaeralis.

Several qualitative and quantitative differences in the emissions of volatile compounds were found in $D$. indica infested cucumber plant compared to the healthy and mechanically damaged plants. Sesquiterpenes like naphthalene $(44.80 \mu \mathrm{g} / \mathrm{mL})$ was found in significant amounts in HIPVs and completely absent in healthy cucumber plant volatiles. Meents et al., (2019) found naphthalene as one of the components of anti-herbivore defense signals released by sweet potato plants.

The present study emphasizes the role of HIPVs released from the $D$. indica infested cucumber plant as well as $D$. indica larval body cues in the host recognition process of specialist parasitic wasp, A. machaeralis. Specialist parasitoids might have innately tuned to HIPVs produced by host plants upon damage by their target herbivore.

\section{ACKNOWLEDGEMENTS}

Authors thank the Director, ICAR-Indian Institute of Horticultural Research, Bangalore for providing research facilities. The technical support from TS Rajanna and J Sagar are highly acknowledged. P. D. Kamala Jayanthi acknowledges the financial support from Indian Council of Agricultural Research through National Fellow project. The senior author thanks Karnataka Science \& Technology Promotion Society (KSTePS) for fellowship support. 


\section{REFERENCES}

Anfora G, Tasin M, Cristofaro AD, Ioriatti C, Lucchi A. 2009. Synthetic grape volatiles attract mated Lobesia botrana females in laboratory and field bioassays. J Chem Ecol. 35: 1054-1062. https://doi.org/10.1007/s10886-0099686-5. PMid:19779942

Cork A, Beevor PS, Gough AJE, Hall DR. 1990. Gas chromatography linked to electoantennography: A versatile technique for identifying insect semiochemicals. pp. 271-279. In: McMaffercy AR, Vilson ID (Eds.). Chromatography isolation of insect hormones and pheromones. Plenum Press, London. https://doi.org/10.1007/978-1-4684-8062-7_26

de Moraes CM, Lewis WJ, Pare PW, Alborn HT, Tumlinson JH. 1998. Herbivore-infested plants selectively attract parasitoids. Nature 393: 570-573. https://doi. org/10.1038/31219

de Rijk M, Krijn M, Jenniskens W, Engel B, Dicke M, Poelman EH. 2016. Flexible parasitoid behaviour comes constraint resulting from position of host and non-host herbivores. Animal Behav. 113: 125-135. https://doi. org/10.1016/j.anbehav.2016.01.001

Dweck HKM, Svensson GP, Akman Gündüz E, Anderbrant O. 2010. Kairomonal response of parasitoid, Bracon hebetor Say, to the male-produced sex pheromone of its host, the greater wax moth, Galleria mellonella (L.). J Chem Ecol. 36: 171-178. https://doi.org/10.1007/ s10886-010-9746-x. PMid:20155500

Harris CM, Ruberson JR, Meagher R, Tumlinson J. 2012. Host suitability affect odor association in Cotesia marginiventris: Implications in generalist parasitoid host-finding. J Chem Ecol. 38: 340-347. https://doi. org/10.1007/s10886-012-0095-9. PMid:22438015

Jayanthi PDK, Woodcock CM, Caulfield J, Birkett MA, Toby JA Bruce. 2012. Isolation and identification of host cues from Mango, Mangifera indica, that attract gravid female Oriental fruit fly, Bactrocera dorsalis. J Chem Ecol. 38: 361-369. https://doi.org/10.1007/s10886-0120093-y. PMid:22438014

Jayanthi PDK, Raghava T, Kempraj V. 2020. Functional diversity of info chemicals in agri-ecological networks. Ipp. 187-192. In: Chakravarthy AK (Ed.). Innovative Pest Management Approaches for the 21st Century. Springer, Singapore. https://doi.org/10.1007/978-98115-0794-6_10
Kigathi RN, Unsicker SB, Reichel TM, Kesselmeier J, Gershenzon J, Weisser WW. 2009. Emission of volatile organic compounds after herbivory from Trifolium pratense (L.) under laboratory and field conditions. J Chem Ecol. 35: 1335-1348. https://doi. org/10.1007/s10886-009-9716-3. PMid:20013039 PMCid:PMC2797619

Kovats E .1965. Gas chromatographic characterization of organic substances in the retention index system. $A d v$ Chromatogr. 1: 229-247.

Meents AK, Chen S, Reichelt M. 2019. Volatile DMNT systemically induces jasmonate- independent direct anti-herbivore defense in leaves of sweet potato (Ipomoea batatas) plants. Sci Rep. 9: 17431. https:// doi.org/10.1038/s41598-019-53946-0. PMid:31758060. PMCid:PMC6874613

Meiners T, Wackers F, Lewis WJ. 2002. The effect of molecular structure on olfactory discrimination by the parasitoid Microplitis croceipes. Chem Senses 27: 811-816. https://doi.org/10.1093/chemse/27.9.811. PMid:12438206

Mumm R, Hilker M. 2005. The significance of background odour for an egg parasitoid to detect plants with host eggs. Chem Senses 30: 337-343. https://doi.org/10.1093/ chemse/bji028. PMid:15788712

Nurkomar I, Manuwoto SP, Buchori D, Matsuyama S, Taylor D, Kainoh Y. 2017. (E, E)-a-Farnesene as a hostinduced plant volatile that attracts Apanteles taragamae (Hymenoptera: Braconidae) to host-infested cucumber plants. Biocontrol Sci Technol. 28: 34-38. https://doi.org /10.1080/09583157.2017.1413340

Ngumbi E, Fadamiro H. 2012. Species and sexual differences in behavioral responses of a specialist and generalist parasitoid species to host-related volatiles. Bull Entomol. Res. 102: 710-718. https://doi.org/10.1017/ S0007485312000326. PMid:22647466

Pare PW, Tumlinson JH. 1999. Plant volatiles as a defense against insect herbivores. Plant Physiol. 121: 325-331. https://doi.org/10.1104/pp.121.2.325

Rains GC, Tomberlin JKD, Alessandro M, Lewis WJ. 2004. Limits of volatile chemical detection of a parasitoid wasp, Microplitis croceipes, and an electronic nose: A comparative study. Trans ASAE 47: 2145-2152. https:// doi.org/10.13031/2013.17785 
VENUGOPAL et al.

Rutledge CE.1996. A survey of identified kairomones and synomones used by insect parasitoids to locate and accept their hosts. Chemoecology 7: 121-131. https:// doi.org/10.1007/BF01245964

Schnee C, Kollner TG, Held M, Turlings TCJ, Gershenzon J. 2006. The products of a single maize sesquiterpene synthase form a volatile defense signal that attracts natural enemies of maize herbivores. Proc Natl Acad Sci. USA. 103: 1129-1134. https://doi. org/10.1073/pnas.0508027103. PMid:16418295. PMCid:PMC1347987

Steidle JLM, SchöllerM.1997. Olfactory host location and learning in the granary weevil parasitoid Lariophagus distinguendus (Hymenoptera: Pteromalidae). J Insect Behav. 10: 331-342. https://doi.org/10.1007/BF02765601

Sullivan BT, Berisford CW. 2004. Semiochemicals from fungal associates of bark beetles may mediate host location behavior of parasitoids. J Chem Ecol. 4: 703-717. https://doi.org/10.1023/B:JOEC.0000028426.37482.17. PMid:15260218
Turlings TCJ, Tumlinson, JH, Lewis WJ .1990. Exploitation of herbivore-induced plant odors by host-seeking parasitic wasps. Science 250: 1251-1253. https://doi. org/10.1126/science.250.4985.1251. PMid:17829213

van Dam NM, Qiu B, Hordijk CA, Vetlem, Jansen JJ. 2010. Identification of biologically relevant compounds in above ground and below ground induced volatile blends. J Chem Ecol. 36: 1006-1016. https://doi. org/10.1007/s10886-010-9844-9. PMid:20737198 PMCid:PMC2941087

Wei J, Kang L. 2006. Electrophysiological and behavioral responses of a parasitic wasp to plant volatiles induced by two leaf miner species. Chem Senses 31: 467-477. https://doi.org/10.1093/chemse/bjj051. PMid:16621971

Wei J, Wang L, Zhu J, ZhangS, Nandi OI, Kang L. 2007. Plants attract parasitic wasps to defend themselves against insect pests by releasing hexenol. PLOS ONE 2: e852. https://doi.org/10.1371/journal.pone.0000852. PMid:17786223. PMCid:PMC1955833 